\title{
Percutaneous Transhepatic Biliary Drainage: A Single-Center Retrospective Study
}

\section{Perkütan Transhepatik Biliyer Drenaj: \\ Tek Merkezli Retrospektif Çalışma}

\author{
Osman DERE ${ }^{1} \mathbb{D}$, Mehmet KOLU ${ }^{2} \mathbb{D}$, Saime SHERMATOVA ${ }^{1} \mathbb{( D )}$, idris KIRHAN ${ }^{3}$
}

\footnotetext{
${ }^{1}$ Harran University Faculty of Medicine, Department of Radiology, Sanliurfa, Turkey.

2 Dicle University Faculty of Medicine, Department of Radiology, Diyarbakir, Turkey

${ }^{3}$ Harran University Faculty of Medicine, Department of Internal Medicine, Sanliurfa, Turkey.
}

Background: Percutaneous transhepatic biliary drainage is a procedure commonly used in malign and benign biliary pathologies. The aim of this study is to evaluate the effectiveness, complication rates and results of percutaneous transhepatic biliary drainage.

Materials and Methods: 49 patients, to whom percutaneous transhepatic biliary drainage was performed due to different malignant and benign pathologies between April 2018 and April 2020 in the interventional radiology department of our hospital, were included in the study. 26 of the patients were male, and 23 were female. The ages of the patients ranged between 8 and 87 , and the mean age was $62.18 \pm 15.8$. External drainage catheter was inserted in 11 patients, and internal-external drainage catheter in 38 patients. Metallic stent was inserted in two patients. The efficiency of the procedures was evaluated according to the comparison of preprocedural and postprocedural direct and total bilirubin values and the improvement in clinical findings. Procedure-related early and late complications were obtained.

Results: Technical success was achieved in all patients who underwent percutaneous transhepatic biliary drainage. The preprocedural and postprocedural total bilirubin median values were $16.2 \mathrm{mg} / \mathrm{dl}(0.6-30.5)$ and $6.3 \mathrm{mg} / \mathrm{dl}(0.7$ 26.9), respectively. The preprocedural and postprocedural direct bilirubin median values were $11.9 \mathrm{mg} / \mathrm{dl}(0.3-15)$ and $4.3 \mathrm{mg} / \mathrm{dl}(0.2-15)$, respectively. The decrease in the total and direct bilirubin values was found to be significant $(p<0.001)$. Major and minor complications developed in 13 patients in the early and late stages.

Conclusions: Percutaneous transhepatic biliary drainage is an efficient method in decompression of malignant biliary obstructions, palliation of the disease and treatment of benign biliary pathologies.

Key Words: Percutaneous, Biliary Drainage, Transhepatic

öz.

Amaç: Perkütan transhepatik biliyer drenaj malign ve benign biliyer patolojilerde sıklıkla uygulanan bir işlemdir.Bu çalışmanın amacı perkütan transhepatik biliyer drenajın etkinliğini, komplikasyon oranlarını ve sonuçlarını değerlendirmektir.

Materyal ve metod: Çalışmaya hastanemiz girişimsel radyoloji bölümünde Nisan 2018- Nisan 2020 tarihleri arasında farklı malign ve benign patolojiler nedeniyle perkütan transhepatik biliyer drenaj uygulanan 49 hasta dahil edildi. Hastaların 26 ' sı erkek, 23 tanesi kadındı. Hastaların yaşları 8-87 arasında değişmekte olup ortalama $62.18 \pm 15.8$ idi. Hastaların 11 tanesine eksternal drenaj kateteri 38 tanesine internal-eksternal drenaj kateteri takıldı. Iki hastaya metalik stent takıldı. Yapılan işlemlerin etkinliği işlem öncesi ve işlem sonrası direkt ve total bilirübin değerlerinin karşılaştırılması ve klinik bulgulardaki düzelmeye göre değerlendirildi. İşleme bağlı erken ve geç dönem komplikasyonlar elde edildi.

Bulgular: İşlem yapılan hastaların tamamında teknik başarı sağlandı. Total bilirübin ortanca değerleri işlem öncesi $16.2 \mathrm{mg} / \mathrm{dl}$ (0.6-30.5) , işlem sonrası $6.3 \mathrm{mg} / \mathrm{dl}$ (0.7-26.9) olarak elde edildi. Direkt bilirübin ortanca değerleri işlem öncesi $11.9 \mathrm{mg} / \mathrm{dl}(0.3-15)$, işlem sonrası $4.3 \mathrm{mg} / \mathrm{dl}(0.2-15)$ idi. Total ve direkt bilirübin değerlerindeki düşüş anlamlı bulundu $(p<0.001)$. İşleme bağlı erken ve geç dönemde 13 hastada majör ve minör komplikasyon gelişti.

Sonuç: Perkütan transhepatik biliyer drenaj malign biliyer obstrüksiyonların dekompresyonunda, hastalığın palyasyonunda ve benign biliyer patolojilerin tedavisinde etkili bir yöntemdir.

Anahtar kelimeler: Perkütan, Biliyer Drenaj, Transhepatik

\section{Corresponding Author / Sorumlu Yazar}

Dr. Osman DERE

Harran University Faculty of Medicine, Department of Radiology,

63000 Sanliurfa,Turkey

e-mail: drderectf@hotmail.com

Received / Geliş tarihi:

07.10 .2021

Accepted / Kabul tarihi: 01.11.2021

DOI: $10.35440 /$ hutfd.1005361 


\section{Introduction}

Percutaneous transhepatic biliary drainage (PTBD) is a minimally invasive method that allows the insertion of a drainage catheter or stent by entering into the biliary system percutaneously in company with imaging (1). PTBD is effectively applied in decompression of malignant biliary obstructions, bile leakage developing due to injury of the bile ducts and in the treatment of benign biliary strictures (2). PTBD can be performed as internal- external biliary drainage (IE-BD) in a way that the distal end of the placed drainage catheter ends in the duodenum or external biliary drainage (E-BD) where the pathological segment cannot be passed and the distal end of the catheter ends at this level.

In patients with malignant biliary obstruction, the first treatment option is the surgical removal of the tumor and enabling bile flow with bilio-enteric anastomoses. However, in the majority of these patients, surgical resection cannot be performed due to the advanced stage of the tumor or its location. Metal stenting is the first treatment method preferred for palliation in malignant biliary obstructions that cannot be operated $(3,4)$.

The objective of this study is to reveal the efficiency and complication rates of PTBD and to report our own results.

\section{Materials and Methods Patient selection}

The records of the patients who underwent PTBD procedure in the interventional radiology department between April 2018 and April 2020 were retrospectively examined. The patients diagnoses, preprocedural and postprocedural total and direct bilirubin values were recorded. In addition, the changes in clinical findings such as jaundice, itching and pain observed in the patients were obtained. Patients with biliary drainage indication and unsuitable for endoscopic drainage were included in the study. The patients who had failed endoscopic biliary drainage (EBD) and underwent percutaneous biliary drainage were also included in the study. Patients with hepatic parenchymal failure, massive ascites and unsuitable for sedoanalgesia were excluded from the study.

\section{Patient preparation and procedure}

Institutional review board approval and an informed consent were obtained for this retrospective study (Approval date and number: March 30, 2020, Session 6, 15946). UItrasonography (US), computed tomography (CT), magnetic resonance (MR) or magnetic resonance cholangiopancreatography (MRCP) were used for diagnostic imaging. Preoperative complete blood count, serum bilirubin values, prothrombin time (PT), partial thromboplastin time (PTT) and international normalized ratio (INR) values of all patients were controlled. The values of the patients with coagulation problem were corrected before the operation. Prophylaxis with cephalosporin group antibiotics were administered to all patients before the operation.
The patients were operated under sedoanalgesia following at least four hours of fasting. All procedures were performed by using fluoroscopy or US-fluoroscopy combination.

Percutaneous transhepatic access was performed under sterile conditions accompanied by US to the right or left intrahepatic bile duct with a 21-G needle which had an internal stylet. Then, the internal stylet of the needle was removed, contrast material was given, and percutaneous transhepatic cholangiography (PTC) was obtained with the help of a C-arm mobile fluoroscopy device. A 0.018 inch guide wire was sent to the bile ducts through a $21-\mathrm{G}$ needle. Then, the tract was dilated with a triple coaxialdilator system (Accustick II Introducer System, Boston Scientific, Natick, Mass., USA), the outer 4F coaxial dilator was left in bile ducts, and the cholangiography images were obtained again. Following this step, a hydrophilic 0.035 inch guide wire (Zipwire, Boston Scientific Corp., Natick, Mass., USA) was used to pass the problematic bile segment and reach the intestine. In some patients, vascular sheaths and diagnostic angiography catheters pushed forward through them were used. After the appropriate access was provided, the hydrophilic wire was passed through the Amplatz wire (SuperStiff, Boston Scientific, USA), and internal- external catheters were placed over this wire. Lastly, with cholangiographies obtained from the catheter, the proximal hole of the catheter was localized in the bile duct and fixed to the skin with suture. In some patients, since access could not be achieved between the intrahepatic bile ducts and the duodenum, an external catheter was placed at the first stage, and a transition to an internal-external catheter was planned in another session. In the patients with postoperative benign strictures, dilatation was performed with balloons of various diameters in the stricture region, and 8F IE-BD catheter was left at the first stage. Then, the patient was followed up at certain time intervals, and the diameter of the inserted catheter was gradually increased.

Patients with malignant obstruction and who were decided to insert a metallic stent were processed in a different session. Cholangiograms were obtained from the existing catheters of these patients, and access was provided over the catheter with Amplatz wire. The catheter was removed, and a hemostatic valve sheath, whose distal end ended in intrahepatic bile ducts, was placed over the same wire. The placed sheath provided support for the placement of the balloon and stent catheters. Before the stent was placed, predilation was performed with balloons of $6 \mathrm{~mm}, 8 \mathrm{~mm}$ and $10 \mathrm{~mm}$ diameters. After this stage, self-expanding metallic stents (Wallstent, Boston Scientific, USA) with appropriate diameter and size in the form of telescopic or $Y$ stents were placed according to the level and extension of the obstruction. After the stent was placed, all patients were dilated with balloons of 6 $\mathrm{mm}, 8 \mathrm{~mm}$ and $10 \mathrm{~mm}$ diameters, the diameter of the stent was increased, its adhering to the wall was enabled, 
and bile passage was increased.

\section{Statistical analysis}

The statistical analyses were performed with SPSS 24.0 version (SPSS Inc, Chicago, IL) package program. Numerical variables were defined as mean \pm standard deviation (Mean $\pm S D$ ), median (minimum-maximum). Categorical variables were defined as percentage (\%). The suitability of the variables to normal distribution was controlled by using the Kolmogorov-Smirnov test. The preprocedural and postprocedural bilirubin values of the patients were compared by using the Wilcoxon Signed Rank Test.

\section{Results}

A total of 49 patients as 26 males and 23 females were included in the study. The ages of the patients ranged between 8 and 87 , and the mean age was $62.18 \pm 15.8$ (Table 1 ). Thirty-eight $(77.5 \%)$ of the patients included in the study underwent PTBD procedure due to malignant obstruction and $11(22.4 \%)$ due to benign biliary pathologies. Twenty of the patients with malignancy had hilar cholangiocarcinoma, 11 had periampullary region tumor, 4 had gallbladder tumors, and 3 had distal bile duct tumors. Five of the patients, who underwent operation for benign biliary pathologies, had strictures in the hepaticojejunostomy anastomosis. Four patients were operated due to anastomotic stricture developed after living donor liver transplantation. PTBD was performed in two patients due to postoperative bile leakage. IE-BD catheter was inserted in 38 patients, while E-BD catheter was inserted in 11 cases (Table 1). In addition, E-BD catheter was inserted for the non-drained side in seven patients in whom IE-BD catheter was inserted. Metallic stenting was performed in two patients with a diagnosis of hilar cholangiocarcinoma and choledoch-invasive gallbladder tumor. The patient with hilar cholangiocarcinoma was predilated with balloons with 6 and $8 \mathrm{~mm}$ diameters, and a $9 \times 80 \mathrm{~mm}$ metallic stent was inserted at the right and left lobe entrances as $Y$ stent. In the patient, no complication developed during and after the procedure. The patient died three months later due to cardiopulmonary arrest. The patient with choledoch-invasive gallbladder tumor was predilated with balloons of 6,8 and $10 \mathrm{~mm}$ diameters, and two metallic stents of $9 \times 70 \mathrm{~mm}$ and $10 \times 40 \mathrm{~mm}$ were inserted telescopically. The stent was followed up in the 5th month patently, and the patient did not come for follow-up afterwards.

The catheter diameter was increased by monitoring the status of the obstruction with monthly follow-ups of the patients who underwent balloon dilatation and 8F IE-BD catheter insertion due to postoperative benign stricture. Catheters were removed in the patients who had sufficient bile flow and improved clinical and laboratory values during follow-ups. In 45 (91.8\%) patients who underwent the procedure, clinical findings such as jaundice and itching were found to regress after the procedure, while $39(79.5 \%)$ patients stated that their pain decreased. The preprocedural total bilirubin median value was 16.2 $\mathrm{mg} / \mathrm{dl}$ (0.6-30.5), while the postprocedural total bilirubin median value was $6.3 \mathrm{mg} / \mathrm{dl}$ (0.7-26.9). The preprocedural and postprocedural direct bilirubin median values were obtained as $11.9 \mathrm{mg} / \mathrm{dl}$ (0.3-15) and $4.3 \mathrm{mg} / \mathrm{dl}$ (0.2$15)$, respectively. A significant decrease was detected in the postprocedural total and direct bilirubin values $(p<0.001)$ (Table 2).

Table 1. Socio-demographic features, diagnoses, biliary drainage type and complication rates of patients

\begin{tabular}{|c|c|}
\hline 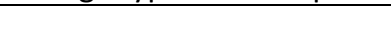 & Mean $\pm S D / n(\%)$ \\
\hline Age & $62.18 \pm 15.8$ \\
\hline \multicolumn{2}{|l|}{ Gender } \\
\hline Male & $26(53.1)$ \\
\hline Female & $23(46.9)$ \\
\hline \multicolumn{2}{|l|}{ Diagnoses } \\
\hline Hilar cholangiocarcinoma & $20(40.8)$ \\
\hline Periampullary region $\mathrm{tm}$ & $11(22.5)$ \\
\hline Gallbladder tm & $4(8.1)$ \\
\hline Distal bile duct tm & $3(6.1)$ \\
\hline $\begin{array}{l}\text { Hepatico-jejunostomy anasto- } \\
\text { motic stenosis }\end{array}$ & $5(10.2)$ \\
\hline $\begin{array}{l}\text { Anastomotic stricture after liver } \\
\text { transplant }\end{array}$ & $4(8.1)$ \\
\hline Bile leak & $2(4.05)$ \\
\hline \multicolumn{2}{|l|}{ Biliary drainage type } \\
\hline IE-BD & $38(77.5)$ \\
\hline E-BD & $11(22.5)$ \\
\hline Metallic stenting & $2(4.05)$ \\
\hline \multicolumn{2}{|l|}{ Complication rates } \\
\hline Minor complications & $10(20.4)$ \\
\hline Major complications & $3(6.1)$ \\
\hline
\end{tabular}

biliary drainage, E-BD: external biliary drainage

Table 2. Change in total and direct bilirubin levels, obtained before and after PTBD procedure

\begin{tabular}{|l|l|l|l|}
\hline \multicolumn{3}{|l|}{} \\
$\begin{array}{l}\text { Median (min- } \\
\text { max) }\end{array}$ & *Before PTBD & *After PTBD & *P value \\
\hline T. Bil (mg/dl) & $\begin{array}{l}16.2 \mathrm{mg} / \mathrm{dl} \\
(0.6-30.5)\end{array}$ & $\begin{array}{l}6.3 \mathrm{mg} / \mathrm{dl} \\
(0.7-26.9)\end{array}$ & $<0.001$ \\
\hline D. Bil (mg/dl) & $\begin{array}{l}11.9 \mathrm{mg} / \mathrm{dl} \\
(0.3-15)\end{array}$ & $\begin{array}{l}4.3 \mathrm{mg} / \mathrm{dl} \\
(0.2-15)\end{array}$ & $<0.001$ \\
& & & \\
\hline
\end{tabular}

*: Values are expressed as median (minimum-maximum) using the Wilcoxon signed rank test. T. Bil: Total bilirubin, D. Bil: Direct bilirubin, PTBD: percutaneous transhepatic biliary drainage

During and after the operation, 10 (20.4\%) of the patients had minor complications while 3 patients had major complications (6.1\%). In four patients, minor complications were self-limiting hemobilia and pain controlled with postoperative analgesics. Cholangitis developed in two patients after the operation. Cholangitis condition improved after the appropriate antibiotherapy. Catheter dislocation occurred in four patients, and their catheters 
were revised. Postoperatively, sepsis developed in one patient as a major complication, and the patient died one day later. Massive hemobilia developed in another patient with periampullary region tumor and liver metastases. On the operation day, no focus was detected in the catheter angiography performed on the patient, and the patient died. Melena developed one month after the procedure in another patient who had a living liver transplantation and was operated due to anastomotic stenosis. In the radiological examination, pseudoaneurysm was detected in the hepatic artery anterior segment branch, and the aneurysm was coiled by catheter angiography (Figure $1,2)$. During the follow-ups, the patient's melena stopped and became clinically stable.

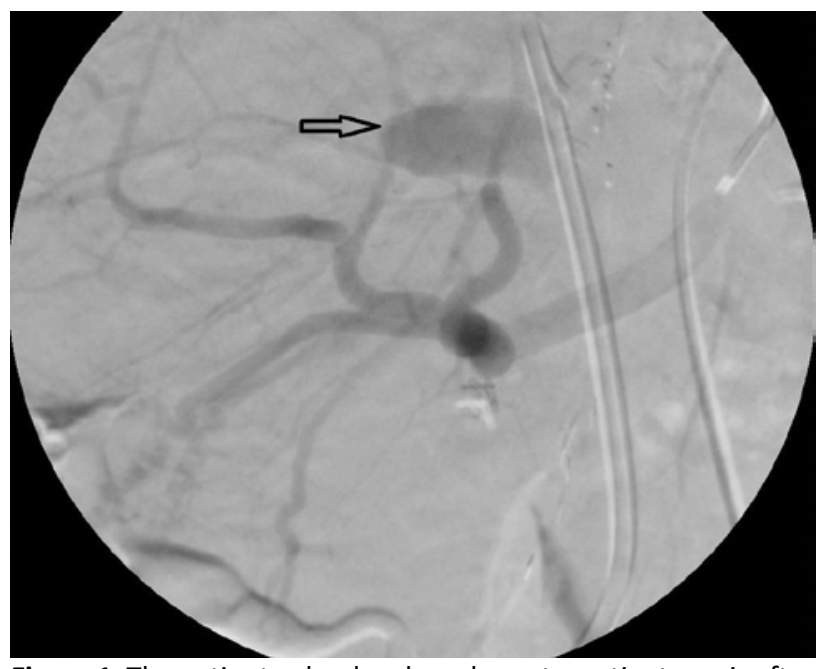

Figure 1. The patient, who developed anastomotic stenosis after living liver transplantation and underwent PTBD, was admitted to the emergency department with melena one month later. A pseudoaneurysm, approximately $23 \times 10 \mathrm{~mm}$ in size, was detected in the hepatic artery anterior segment branch in the patient who underwent digital substraction angiography (open arrow).

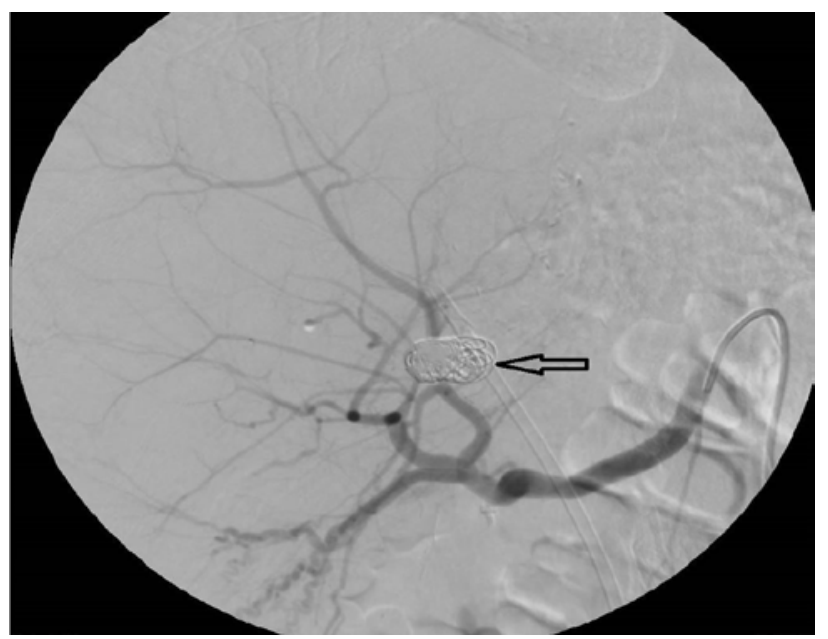

Figure 2. The pseudoaneurysm of the same patient was treated with coil by super-selective insertion into the hepatic artery anterior segment branch (open arrow).

\section{Discussion}

Percutaneous transhepatic biliary drainage is a procedure frequently applied in the practice of interventional radiology, in the treatment of many benign biliary pathologies, treatment and/or palliation of malignant biliary obstruction. Among malignant etiologies in patients who undergo drainage, periampullary region tumors, gallbladder carcinoma, cholangiocarcinoma, pancreatic adenocarcinoma and metastatic lymphadenopathy constitute the majority of cases (3). In our study, the most common malignant etiology in patients with PTBD was found to be hilar cholangiocarcinoma. In addition to symptoms such as itching and jaundice in biliary obstruction, clinical conditions such as cholangitis, liver and kidney failure secondary to cholestasis may develop. High bilirubin levels increase postoperative morbidity and mortality in patients with malignant biliary obstruction. Therefore, it is necessary to decrease the bilirubin values before the operation in these patients. Moreover, high bilirubin levels constitute a contraindication in patients who need chemotherapy and radiotherapy and in the application of local treatments such as radiofrequency ablation and transarterial chemo-radioembolization (6). In malignant obstruction, EBD, PTBD and surgical biliary reconstruction can be performed to enable bile flow (7). Although the surgical method is effective, it cannot be applied in most of the patients due to the accompanying morbidities and the stage of the disease. Drainage is provided with EBD or PTBD procedure (8). Although there are different results in the literature regarding the efficacy of EBD and PTBD in biliary drainage and complication rates, the generally accepted opinion is to perform EBD in distal obstructions and PTBD in proximal obstructions $(1,3,9)$. In our study, EBD was first tried in the patients with distal obstruction, and PTBD was performed in the patients who had failed operation due to tumoral invasion of the ampulla. In addition, metallic stenting was performed in two patients who had malignant biliary stenosis and could not be surgically and endoscopically palliated.

Benign pathologies requiring biliary drainage are mostly postoperative anastomotic strictures, stone disease, sclerosing cholangitis and bile leakage (5). If benign biliary strictures are not treated, they may result in recurrent cholangitis, biliary cirrhosis, liver failure and death (10). Surgical approach, endoscopic stent insertion or PTBD can be applied in the treatment of benign biliary strictures. Therefore, evaluation of the patient by a team consisting of surgeon, gastroenterologist and interventional radiologist to decide which treatment method will be applied will increase the success rate. Various methods such as percutaneous biliary drainage catheter placement, balloon dilatation and stent placement can be used in the treatment of benign biliary stricture. Although all of these methods are used in interventional radiology practice, there is no consensus on the ideal technique (11). Patient's age, comorbidities, location and etiology of the 
stricture are decisive in terms of selecting the treatment method $(12,13)$. The percutaneous transhepatic approach is mostly preferred in intrahepatic stenosis cases, in cases where the endoscopic approach is unsuccessful or when EBD cannot be performed such as hepaticojejunostomy $(14,15)$. In our series, the majority of the patients had postoperative anastomotic strictures, while two patients were operated due to bile leakage.

Our technical success was achieved as $100 \%$ in the patients who underwent PTBD within the specified date range. A decrease in bilirubin levels was achieved in $92 \%$ of patients. In the literature, the decrease in bilirubin levels has been reported as $80 \%$ and above $(16,17)$.

Complications in percutaneous transhepatic biliary drainage operation are divided into two as minor and major complications. Major complications can be listed as the development of bleeding that requires blood transfusion, necessity of treatment in the intensive care unit after the operation, need for additional percutaneous drainage such as bilioma, hematoma, pneumothorax or bronchopleural fistula, stopping the bleeding with catheter angiography and death associated with the operation (16). In the literature, major complication rates vary between $4-25 \%$, and the mortality rates associated with the procedure have been reported as 0-5.6\% (16). In our study, in accordance with the literature, the rate of major complications was found as $6.1 \%$. The procedure-related mortality rate was found to be $4 \%$. In a study conducted by Berquist et al., it was reported that more than $30 \%$ of the patients who underwent PTBD had cholangitis and more than $10 \%$ had sepsis (18). In a prospective study conducted by Clark et al. where they performed 480 biliary operations, $1 \mathrm{~g}$ cefotetan was given to the patients before the operation, and the sepsis rate was obtained as $2 \%$ (19). We also started with 1 g ceftriaxone prophylactically in all our patients before the procedure. Similarly, $2 \%$ of the patients developed postoperative sepsis. Although there is no consensus regarding the necessity of using prophylactic antibiotics in the literature, based on the results we obtained, we think that routine antibiotic prophylaxis should be performed $(1,16)$. In the studies conducted, postoperative 30-day mortality rates are observed in the range of $4-30 \%(3,4,6,9,20)$. In our study, the 30 -day mortality rate was found to be $10 \%$. Procedurerelated mortality was observed in two of these patients, and the other three patients died due to disease progression or comorbidities.

The relatively low number of the participants and the retrospective study design are considered as the limitations of our study.

In conclusion, PTBD is an efficient and reliable method performed for the treatment and palliation of malign and benign biliary pathologies. The preprocedural and postprocedural complication rates are at a tolerable level, and the percutaneous treatment of some complications that may develop increases the applicability of the method.
Ethical Approval: This study conformed to the principles of the 2008 Declaration of Helsinki and was approved by the local ethics committee of Harran University, Medical Faculty, Turkey (Approval date: 30.03.2020 Number HRU/20.06.04).

\section{Author Contributions:}

Concept: O.D., M.K., I.K.

Literature Review: O.D., S.S.

Design : O.D.

Data acquisition: O.D., M.K., I.K.

Analysis and interpretation: O.D., M.K.

Writing manuscript: O.D.

Critical revision of manuscript: O.D., M.K.

Conflict of Interest: The authors have no conflicts of interest to declare.

Financial Disclosure: Authors declared no financial support.

\section{References}

1. Covey AM, Brown KT. Percutaneous transhepatic biliary drainage. Tech Vasc Interv Radiol 2008;11: 14.

2. Kim ES, Lee BJ, Won JY, Choi JY, Lee DK. Percutaneous transhepatic biliary drainage may serve as a successful rescue procedure in failed cases of endoscopic therapy for a post-living donor liver transplantation biliary stricture. Gastrointest Endosc 2009; 69: 38-46.

3. Van Delden OM, Laméris JS. Percutaneous drainage and stenting for palliation of malignant bile duct obstruction. Eur Radiol 2008; 18: 448-56.

4. Makino T, Fujitani K, Tsujinaka T, Hirao M, Kashiwazaki M, Nakamori $\mathrm{S}$, et al. The role of percutaneous transhepatic biliary drainage in patients with obstructive jaundice caused by local recurrence of gastric cancer. Hepatogastroenterology 2008; 55 : 54-7.

5. Venbrux AC, Osterman FA Jr. Percutaneous management of benign biliary strictures. Tech Vasc Interv Radiol 2001; 4: 141-6 6. Zhang GY, Li WT, Peng WJ, Li GD, He XH, Xu LC. Clinical outcomes and prediction of survival following percutaneous biliary drainage for malignant obstructive jaundice. Oncol Lett. 2014;7:1185-90.

7. Chu D, Adler DG. Malignant biliary tract obstruction: Evaluation and therapy. J. Natl Compr. Canc. Netw. 2010; 8: 1033-44. 8. Zhao XQ, Dong JH, Jiang K, Huang XQ, Zhang WZ. Comparison of percutaneous transhepatic biliary drainage and endoscopic biliary drainage in the management of malignant biliary tract obstruction: a meta-analysis. Dig Endosc. 2015 ;27:137-45.

9. Crosara Teixeira M, Mak MP, Marques DF, Capareli F, Carnevale FC, Moreira AM, et al. Percutaneous transhepatic biliary drainage in patients with advanced solid malignancies: Prognostic factors and clinical outcomes. J Gastrointest Cancer. 2013;44:398-403.

10. Csendes A, Diaz C, Burdiles P, Nava O, Yarmuch J, Maluenda $F$, et al. Indications and results of hepaticojejunostomy in benign strictures of the biliary tract. Hepatogastroenterology, 1992; 39 : 333-6.

11. Kapoor BS, Mauri G, Lorenz JM. Management of Biliary Strictures: State-of-the-Art Review. Radiology. 2018;289:590-603.

12. Frattaroli FM, Reggio D, Guadalaxara A, Illomei G, Pappalardo G. Benign biliary strictures: a review of 21 years of experience. J Am Coll Surg, 1996; 183: 506-13.

13. Lillemoe KD, Pitt HA, Cameron JL. Current management of benign bile duct strictures. Adv Surg, 1992; 25: 119-74. 
14. Born P, Rösch T, Brühl K, Sandschin W, Allescher HD, Frimberger $E$, et al. Long-term results of endoscopic and percutaneous transhepatic treatment of benign biliary strictures. Endoscopy, 1999; 31: 725-31.

15. Schumacher $B$, Othman $T$, Jansen $M$, Preiss $C$, Neuhaus $H$. Long-term follow-up of percutaneous transhepatic therapy (PTT) in patients with definite benign anastomotic strictures after hepaticojejunostomy. Endoscopy, 2001; 33: 409-15.

16. Weber A, Gaa J, Rosca B, Born P, Neu B, Schmid RM, et al. Complications of percutaneous transhepatic biliary drainage in patients with dilated and nondilated intrahepatic bile ducts. Eur J Radiol 2009;72:412-7.

17. Pappas $P$, Leonardou $P$, Kurkuni $A$, Alexopoulos $T$, Tzortzis $G$. Percutaneous insertion of metallic endoprostheses in the biliary tree in 66 patients: relief of the obstruction. Abdom Imaging 2003;28:678-83.

18. Berquist TH, May GR, Johnson CM, Adson MA, Thistle JL. Percutaneous biliary decompression: internal and external drainage in 50 patients. Am J Radiol 1981;136(5):901-6.

19. Clark CD, Picus $D$, Dunagan WC. Bloodstream infections after interventional procedures in the biliary tract. Radiology 1994;191:495-9.

20. Arıbaş BK, Arda K, Yakut F, Yılmaz K, Doğan K, Şahin G, ve ark. Malign bilier obstrüksiyonlarda ve eşlik eden bilomalarda perkütan bilier drenaj. Akademik Gastroenteroloji Dergisi 2010;9: 1621. 